\title{
Fast and Slow Oscillations Recruit Molecularly- Distinct Subnetworks of Lateral Hypothalamic Neurons In Situ
}

\author{
Christin Kosse, and ${ }^{\circledR D e n i s}$ Burdakov
}

DOI:http://dx.doi.org/10.1523/ENEURO.0012-18.2018

Neurophysiology Laboratory, The Francis Crick Institute, London NW1 1AT, United Kingdom

\begin{abstract}
Electrical signals generated by molecularly-distinct classes of lateral hypothalamus (LH) neurons have distinct physiological consequences. For example, LH orexin neurons promote net body energy expenditure, while LH non-orexin neurons [VGAT, melanin-concentrating hormone $(\mathrm{MCH})$ ] drive net energy conservation. Appropriate switching between such physiologically-opposing LH outputs is traditionally thought to require cell-type-specific chemical modulation of LH firing. However, it was recently found that, in vivo, the LH neurons are also physiologically exposed to electrical oscillations of different frequency bands. The role of the different physiological oscillation frequencies in firing of orexin vs non-orexin LH neurons remains unknown. Here, we used brain-slice whole-cell patch-clamp technology to target precisely-defined oscillation waveforms to individual molecularly-defined classes LH cells (orexin, VGAT, MCH, GAD65), while measuring the action potential output of the cells. By modulating the frequency of sinusoidal oscillatory input, we found that high-frequency oscillations $(\gamma, \approx 30-200 \mathrm{~Hz})$ preferentially silenced the action potential output orexin $\mathrm{LH}_{\mathrm{LH}}$ cells. In contrast, low frequencies $(\delta-\theta, \approx 0.5-7 \mathrm{~Hz})$ similarly permitted outputs from different LH cell types. This differential control of orexin and non-orexin cells by oscillation frequency was mediated by cell-specific, impedance-unrelated resonance mechanisms. These results substantiate electrical oscillations as a novel input modality for cell-type-specific control of LH firing, which offers an unforeseen way to control specific cell ensembles within this highly heterogeneous neuronal cluster.
\end{abstract}

Key words: electrophysiology; hypocretin; hypothalamus; $\mathrm{MCH}$; orexin; oscillations

\section{Significance Statement}

Neurons that emit opposing control signals are physically intermixed in the mammalian hypothalamus. How to achieve selective control of particular hypothalamic signals remains a fundamental unsolved question in both basic science and clinical practice. Traditionally, such cell-selective control is only thought to be possible by chemicals, while electricity is assumed to be too nonselective. We investigated this assumption by exploring the effects of biologically-relevant electrical oscillations on signals emitted by specific types of hypothalamic cells. Unexpectedly, some oscillation frequencies switched off certain hypothalamic signals (orexin signals) while preserving others (non-orexin signals), via a cell-selective resonance mechanism. These findings increase our understanding of how the hypothalamus can be controlled.

\section{Introduction}

The lateral hypothalamus (LH) controls states of consciousness, energy balance, and motivated behavior in

Received January 8, 2018; accepted January 25, 2018; First published January 31, 2018.

The authors declare no competing financial interests. mammals (Saper et al., 2001; Stuber and Wise, 2016). Several molecularly and physiologically -distinct types of $\mathrm{LH}$ neurons exist. Orexin/hypocretin ${ }_{\mathrm{LH}}$ neurons promote 
generalized (cortical and sympathetic) arousal and net energy use; their hypoactivity evokes energy conservation, weight gain, and pathologic intermixing of sleep and wakefulness, and their hyperactivity is associated with stress and anxiety (Chemelli et al., 1999; Hara et al., 2001; Boutrel et al., 2005; Suzuki et al., 2005; Adamantidis et al., 2007; Sakurai, 2014; Bonnavion et al., 2015). VGAT ${ }_{\mathrm{LH}}$ neurons promote consumptive behaviors leading to net energy gain: their hypoactivity reduces body weight, eating, and arousal; and their hyperactivity promotes overeating and hyperarousal (Jennings et al., 2015; Herrera et al., 2016; Venner et al., 2016). Melanin-concentrating hormone $\left(\mathrm{MCH}_{\mathrm{LH}}\right)$ neurons promote memory-associated brain states, suppress locomotion, and promote weight gain (Shimada et al., 1998; Jego et al., 2013; Whiddon and Palmiter, 2013). GAD65 $\mathrm{LH}$ neurons, which do not overlap with the orexin $n_{\mathrm{LH}}$ and $\mathrm{MCH}_{\mathrm{LH}}$ neurons and only partly overlap with VGAT $\mathrm{T}_{\mathrm{LH}}$ cells, are necessary and sufficient for normal locomotion (Kosse et al., 2017).

Differential control of these physiologically-distinct LH drives is presumably required for proper physiological regulation and for avoiding co-occurrence of contradictory drives. This control has been a subject of intense research, revealing cell-type-specific modulation of the LH by chemical agents such as nutrients, hormones, neurotransmitters, and gasses ( $\mathrm{Li}$ et al., 2002; Yamanaka et al., 2003; van den Pol et al., 2004; Burdakov et al., 2005; Williams et al., 2007; Karnani et al., 2011; Burdakov et al., 2013; Karnani et al., 2013). Apart from these chemical signals, many brain regions, including the $\mathrm{LH}$, contain electrical oscillations (Gray and Singer, 1989; Salinas and Sejnowski, 2001; Buzsáki and Draguhn, 2004; CarusCadavieco et al., 2017). These oscillations are thought to control brain states and behaviors in a frequencydependent manner, for example, fast oscillations ( $\gamma$ frequencies, $\approx 30-200 \mathrm{~Hz}$ ) orchestrate arousal, memory, sensory processing, and decision-making (Cardin et al., 2009; Colgin et al., 2009; Buzsáki and Wang, 2012; Yamamoto et al., 2014). In the LH, $\gamma$ oscillations, controlled in part by inputs from the lateral septum, were recently found to be associated with food approach behavior, and differentially affect subthreshold membrane potential of $\mathrm{MCH}_{\mathrm{LH}}$ and $\mathrm{VGAT}_{\mathrm{LH}}$ cells (Carus-Cadavieco et al., 2017). However, it remains unknown whether different oscillations frequencies differentially modulate the physiologic output (action potential firing rate) of orexin versus non-orexin neurons.

Oscillations shape the synaptic inputs onto individual neurons, which collectively results in sinusoidal oscillations of current input at varying frequencies in neurons recorded intracellularly in vivo (Leung and Yim, 1986;

\footnotetext{
core funding from Cancer Research UK, the United Kingdom Medical Research Council, and the Wellcome Trust.

Correspondence should be addressed to Denis Burdakov at the above address, E-mail: d.burdakov@oxon.org.

DOI:http://dx.doi.org/10.1523/ENEURO.0012-18.2018

Copyright (C) 2018 Kosse and Burdakov

This is an open-access article distributed under the terms of the Creative Commons Attribution 4.0 International license, which permits unrestricted use, distribution and reproduction in any medium provided that the original work is properly attributed.
}

Soltesz and Deschênes, 1993). Neurons control longrange targets by action potentials fired in response to the input signals. Understanding how the firing rates of molecularly-defined LH neurons respond to oscillatory input currents may thus reveal a new dimension of $\mathrm{LH}$ output tuning and input-output information transfer. Using experimental paradigms established for studying the effects of oscillations on neuronal firing in other brain regions (Pike et al., 2000), here we explored how the firing of individual, molecularly-defined LH neurons is modulated by the frequency of oscillatory current inputs.

\section{Materials and Methods}

\section{Identification of molecularly-distinct cell classes by transgenic labeling}

All procedures followed United Kingdom Home Office regulations and were approved by local welfare committees. Adult male and female mice (at least eight weeks old) were kept on a standard 12/12 h light/dark cycle and on standard mouse chow and water ad libitum. Mice were anaesthetized with isoflurane and injected with Meloxicam (2 mg/kg bodyweight, s.c.) for analgesia. After placing into a stereotaxic frame (David Kopf Instruments), a craniotomy was performed and a borosilicate glass pipette was used to inject viral vectors into the LH bilaterally with pressure (coordinates AP/DV/ML $=-1.3 /-5.15$ to $-5.25 / 1.0,-1.0 \mathrm{~mm}$; infusion speed $=75 \mathrm{nl} / \mathrm{min}$, injection volume $75 \mathrm{nl})$. Mice were allowed to recover for at least two weeks after surgery while single housed. To study $\mathrm{LH} \mathrm{MCH}$ cells, we labeled them with mCherry by injecting into the $\mathrm{LH}$ a lentiviral vector specifically expressing mCherry in $\mathrm{MCH}$ neurons VSVG.HIV.MCH.mCherry(p2428) $\left(3.16 \times 10^{-11} \mathrm{gc} / \mathrm{ml}\right.$, vector described and validated in Apergis-Schoute et al., 2015). To study LH orexin neurons, we used either the previously characterised and validated orexin-eGFP mice (Burdakov et al., 2006), or labeled LH orexin cells by injecting into the LH an orexin promoter-dependent adeno-associated vector specifically expressing GCaMP6s in orexin cells (AAV1.hORX. GCaMP6s.hGH, $2.53 \times 10^{-12} \mathrm{gc} / \mathrm{ml}$, vector described and validated in González et al., 2016). To study LH VGAT or GAD65 cells, we used GAD65-GFP mice (Karnani et al., 2013) crossed with VGAT-Ires-Cre mice (Vong et al., 2011) and CAG-tdTomato mice (Madisen et al., 2010); and made recordings from GFP(+)/tdTomato(-) or GFP()/tdTomato(+) cells that corresponded to GAD65(+)/ VGAT(-) and VGAT(+)/GAD65(-) cells, respectively (Kosse et al., 2017).

\section{Chemicals and solutions}

For brain slice recordings, artificial CSF (ACSF) and ice-cold slicing solution were gassed with $95 \% \mathrm{O}_{2}$ and $5 \% \mathrm{CO}_{2}$, and contained the following ACSF: $125 \mathrm{mM}$

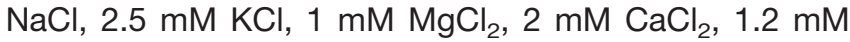
$\mathrm{NaH}_{2} \mathrm{PO}_{4}, 21 \mathrm{mM} \mathrm{NaHCO}, 2 \mathrm{mM}$ D-(+)-glucose, 0.1 $\mathrm{mM} \mathrm{Na}$ +-pyruvate, and $0.4 \mathrm{mM}$ ascorbic acid. Slicing solution: $2.5 \mathrm{mM} \mathrm{KCl}, 1.3 \mathrm{mM} \mathrm{NaH}_{2} \mathrm{PO} . \mathrm{H}_{2} \mathrm{O}, 26.0 \mathrm{mM}$ $\mathrm{NaHCO}_{3}, 213.3 \mathrm{mM}$ sucrose, $10.0 \mathrm{mM} \mathrm{D}$-(+)-glucose, 2.0 $\mathrm{mM} \mathrm{MgCl}$, and $2.0 \mathrm{mM} \mathrm{CaCl}_{2}$. For standard whole-cell recordings, pipettes were filled with intracellular solution 
Table 1. Passive electrical properties of neurons analyzed in this study

\begin{tabular}{lcccc}
\hline & $\mathrm{MCH}$ & Orexin & GAD65 & VGAT \\
Membrane resistance $(\mathrm{M} \Omega)$ & $474.8571 \pm 54.2614$, & $463.0385 \pm 56.76324$, & $619.2471 \pm 49.09955$, & $724.4438 \pm 92.54686$, \\
& $n=14$ & $n=13$ & $n=17$ & $n=16$ \\
Membrane time constant $(\mathrm{ms})$ & $40.60857 \pm 6.530006$, & $43.24915 \pm 7.335909$, & $32.42376 \pm 4.217719$, & $32.54188 \pm 3.505608$, \\
& $n=14$ & $n=13$ & $n=17$ & $n=16$
\end{tabular}

containing the following: $120 \mathrm{mM} \mathrm{K}$-gluconate, $10 \mathrm{mM}$ $\mathrm{KCl}, 10 \mathrm{mM}$ HEPES, $0.1 \mathrm{mM}$ EGTA, 4 mM K $\mathrm{K}_{2} \mathrm{ATP}, 2 \mathrm{mM}$ $\mathrm{Na}_{2}$ ATP, $0.3 \mathrm{mM} \mathrm{Na}_{2} \mathrm{GTP}$, and $2 \mathrm{mM} \mathrm{MgCl}_{2}, \mathrm{pH} 7.3$ with $\mathrm{KOH}$. All chemicals were from Sigma or Tocris Bioscience.

\section{Acquisition and analysis of electrophysiological data}

Standard whole-cell slice patch-clamp recordings were conducted as described in detail in our previous studies (Schöne et al., 2014). Briefly, LH slices were prepared at least two weeks after the virus injection. After gluing a block of brain with cyanoacrylate glue to the stage of a Campden Vibroslice, coronal brain slices $(250-\mu \mathrm{m}$ thickness) containing the LH were cut while immersed in icecold slicing solution. Slices were incubated for $1 \mathrm{~h}$ in
ACSF at $35^{\circ} \mathrm{C}$, then transferred to a submerged-type recording chamber. Living neurons containing fluorescent markers were visualized in acute brain slices with an upright Olympus BX61WI microscope equipped with an oblique condenser and appropriate fluorescence filters. Data were acquired with HEKA Patchmaster and analyzed with HEKA Fitmaster, GraphPad Prism and Matlab.

To determine the frequency preference for action potential firing, a protocol of 5-s-long sinusoidal currents at the following fixed frequencies was applied: 0.5, 1, 2, 3, 5, $7,10,15,20,30,50,70,100$, and $200 \mathrm{~Hz}$. A minimum of 20 -s stable baseline recording was obtained before the sinusoidal stimulations, and the stimulations were applied with an interval of $5 \mathrm{~s}$. Membrane time constants $(\tau)$ were calculated from fitting a single exponential function to the
A

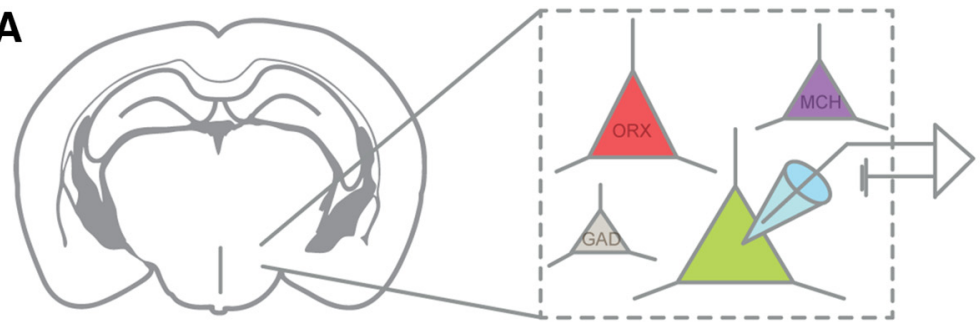

B
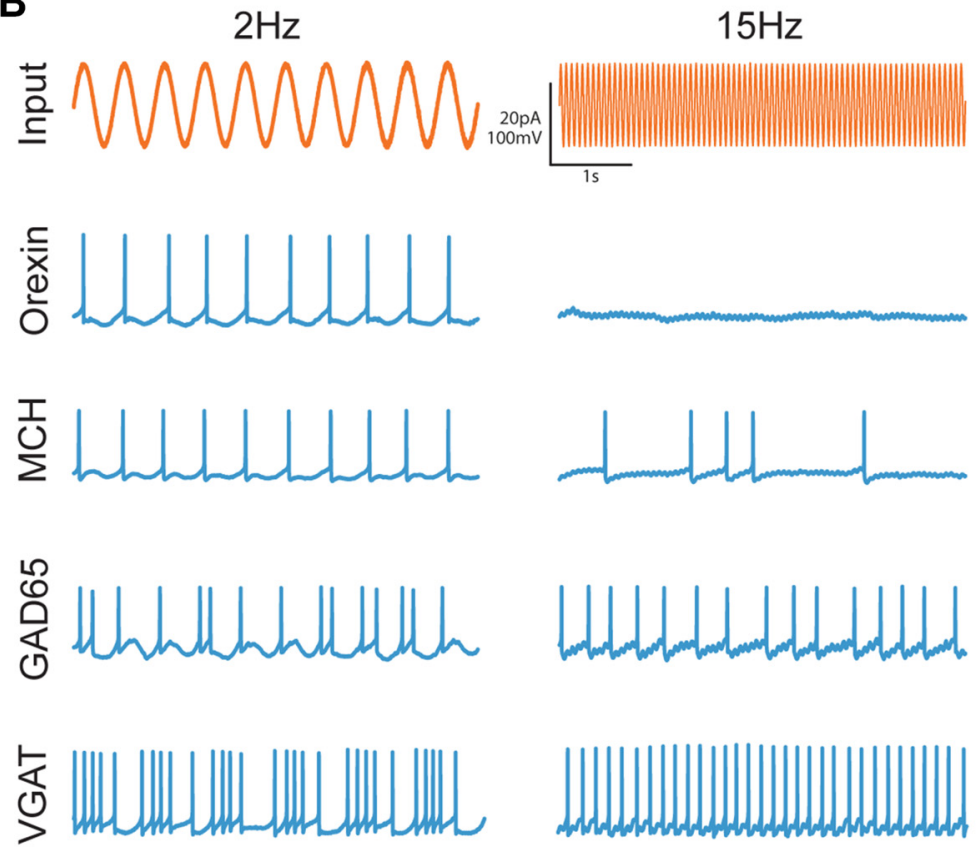

Current injected

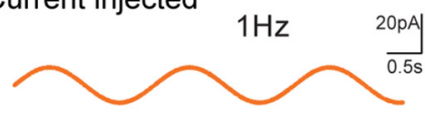

Membrane potential

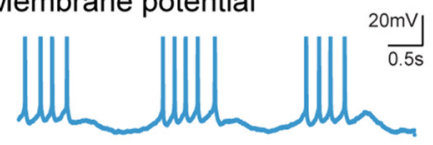

$100 \mathrm{~Hz}$
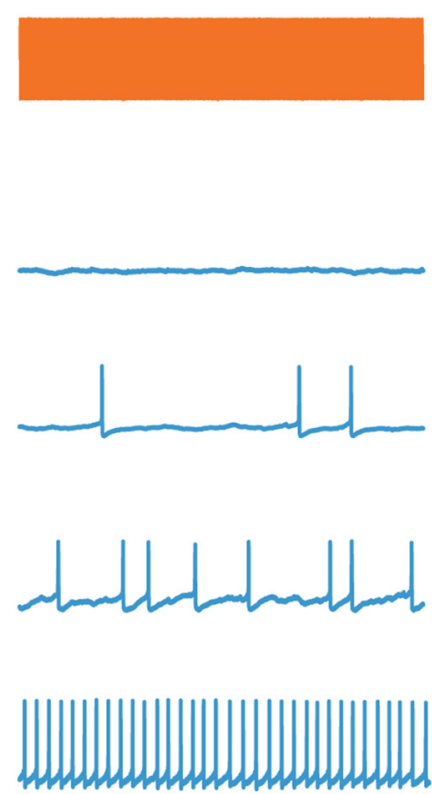

Figure 1. $\boldsymbol{A}$, Overview of experimental strategy. Cell types were genetically tagged with a fluorophore to target patch-clamp recordings. During whole-cell recordings, 5-s-long oscillatory current at fixed frequencies were injected into the cells to obtain an action potential output corresponding to each frequency. $\boldsymbol{B}$, Individual example raw traces of single cells of the investigated cell types at three different input frequencies. 

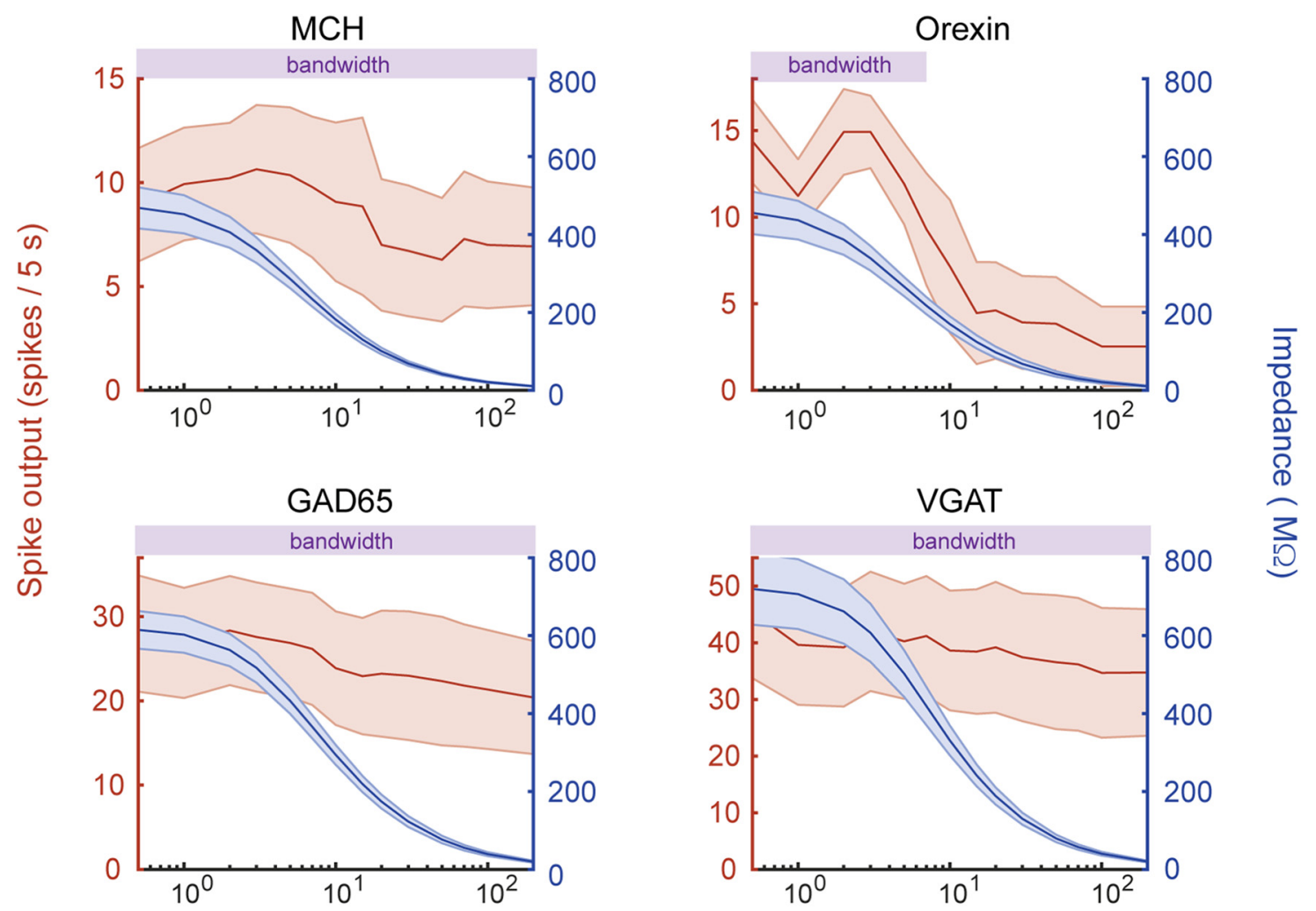

Oscillation frequency $(\mathrm{Hz})$

Figure 2. Effects of input oscillation frequency on LH cell population firing rates (spike output, red) and impedances (blue). Bandwidth bars (purple) denote oscillation frequencies at which there was significant (non-zero) spike output (calculated by one-sample $t$ tests and corrected for multiple comparisons by controlling the false discovery rate, see Materials and Methods). Values are mean \pm SEM. Cell numbers for $\mathrm{MCH}$, orexin, GAD65, and VGAT neurons are 14, 13, 17, and 16, respectively.

initial part of a voltage response to a small hyperpolarising current pulse, and input resistances $\left(R_{i}\right)$ were derived from Ohm's law by fitting a linear function to the current-voltage relationship of voltage responses to hyperpolarising current pulses (Table 1). From these values, the input frequency $(f)$ dependence of membrane impedance $(Z)$ was calculated as follows (based on Gutfreund et al., 1995; Pike et al., 2000):

$$
|Z|=R_{i} / \sqrt{\left(\tau^{2}(2 \pi f)^{2}+1\right)}
$$

\section{Experimental design and statistical analysis}

Cells were randomly recorded throughout the anatomic extent of the $\mathrm{LH}$, by choosing fluorescent neurons using an objective that blinded the experimenter to intra-LH location of the cell due to its small field of view (a highmagnification $40 \times$ objective). After recording, the intra-LH locations of recorded neurons were confirmed using a large-field (low magnification) objective. Statistical tests and descriptive statistics were performed as stated in the figure legends. Before performing parametric tests, data were assessed for normality with a D'Agostino-Pearson omnibus test or Kolmogorov-Smirnov test and variances were assessed for homogeneity with a Brown-Forsythe test. To compare interactions within data with repeated measurements, ANOVA was used, and if significant inter- actions were found, multiple comparison tests followed. Normalizations were performed on a single cell basis by dividing by the largest value obtained per cell. Cells were deemed active if a paired $t$ test comparing normalized firing and impedance values was significant after controlling for the false discovery rate (which was set to $5 \%$ ) by a two-stage step-up method of Benjamini, Krieger, and Yekutieli. Analysis was performed with GraphPad Prism and Matlab.

\section{Results}

\section{Distinct frequency preferences of molecularly- distinct LH subnetworks}

To explore how different LH neurons respond to oscillatory inputs, we selectively targeted fluorescent reporters to LH orexin, VGAT, MCH, or GAD65 cells (see Materials and Methods) and recorded the membrane potential responses of individual genetically-defined LH cells to sinusoidal input currents at a broad range of physiological frequencies $(0.5-200 \mathrm{~Hz}$; Fig. 1). To facilitate comparisons between neurons, and to previous studies of neuronal responses to oscillations in other brain areas (Pike et al., 2000), the recordings were performed at the membrane potentials close to threshold for spike generation. This was achieved by superposing an oscillatory current on the 
maximum step current that itself did not elicit spikes, and using a small $(20 \mathrm{pA})$ peak-to-peak sinusoidal current (based on Pike et al., 2000).

Low input frequencies $(\approx 0.5-20 \mathrm{~Hz})$ resulted in robust spiking activity in all LH neuronal types (Figs. 1, 2). In contrast, higher frequencies selectively silenced orexin neurons (cessation of significant firing at inputs above 7 $\mathrm{Hz}$; Fig. $2 A$ ), while preserving significant firing in non-orexin cell types (Fig. 2B-D). These differences in frequencypreferences of $\mathrm{LH}$ neuron firing did not appear to be related to their maximal firing rates or spike-rate adaptation. Specifically, the firing of non-orexin neurons stayed relatively invariant across oscillation frequencies, irrespective of whether their maximal firing rates were fast (VGAT, GAD65 cells) or slow (MCH cells), and irrespective of whether their spike-rate adaptation was high $(\mathrm{MCH}$ cells; van den Pol et al., 2004; Burdakov et al., 2005) or Iow (GAD65 cells; Karnani et al., 2013). In turn, orexin cell firing had higher frequency-dependent decay than nonorexin cell firing, although their initial firing was faster than $\mathrm{MCH}$ cells but slower than VGAT or GAD65 cells (Fig. 2), and their spike-rate adaptation was lower than that of $\mathrm{MCH}$ cells (Burdakov et al., 2005). Thus, there are distinct frequency-bandwidths for optimal firing of orexin and non-orexin LH neurons, which cannot be accounted for by previously-studied differences in their intrinsic excitability.

These distinct frequency dependencies of firing in orexin and non-orexin neurons could, in theory, emerge from distinct frequency dependencies of the passive membrane impedances (Pike et al., 2000). Higher membrane impedance would produce greater membrane potential fluctuations in response to oscillatory inputs and thus produce greater membrane excitation and firing (Pike et al., 2000). To investigate whether such passive membrane resonance could account for the differences in spike frequency preferences (Fig. 2, red plots), we used our data to compute impedances of RC equivalent circuits at each input frequency for individual LH neurons (Fig. 2, blue plots; see Materials and Methods). Although maximum impedances differed between cell types (orexin $=\mathrm{MCH}<$ GAD65 $<$ VGAT neurons; Fig. 2), all impedances decayed similarly with input oscillation frequency, and this decay and did not follow the associated frequency-tuning of firing (Fig. 2, compare red and blue plots).

To compare the frequency-tuning of firing and impedances between different LH cell types, independently of differences of absolute values in these parameters, we normalized each neuron to its own maximal firing and impedance (Fig. 3; see Materials and Methods). Similar to raw data (Fig. 2), this revealed that orexin cell firing decayed more steeply with oscillation frequency than that of non-orexin cells (Fig. $3 A$; within these normalized data, the decay was significantly different between orexin and VGAT or GAD65 cells, but not between orexin and $\mathrm{MCH}$ cells; Fig. $3 B$ ). This difference between orexin and VGAT/ GAD65 cells emerged sharply at $>7 \mathrm{~Hz}$ and persisted at higher frequencies (Fig. 3B). In contrast, there was an almost perfect overlap in the frequency dependence of
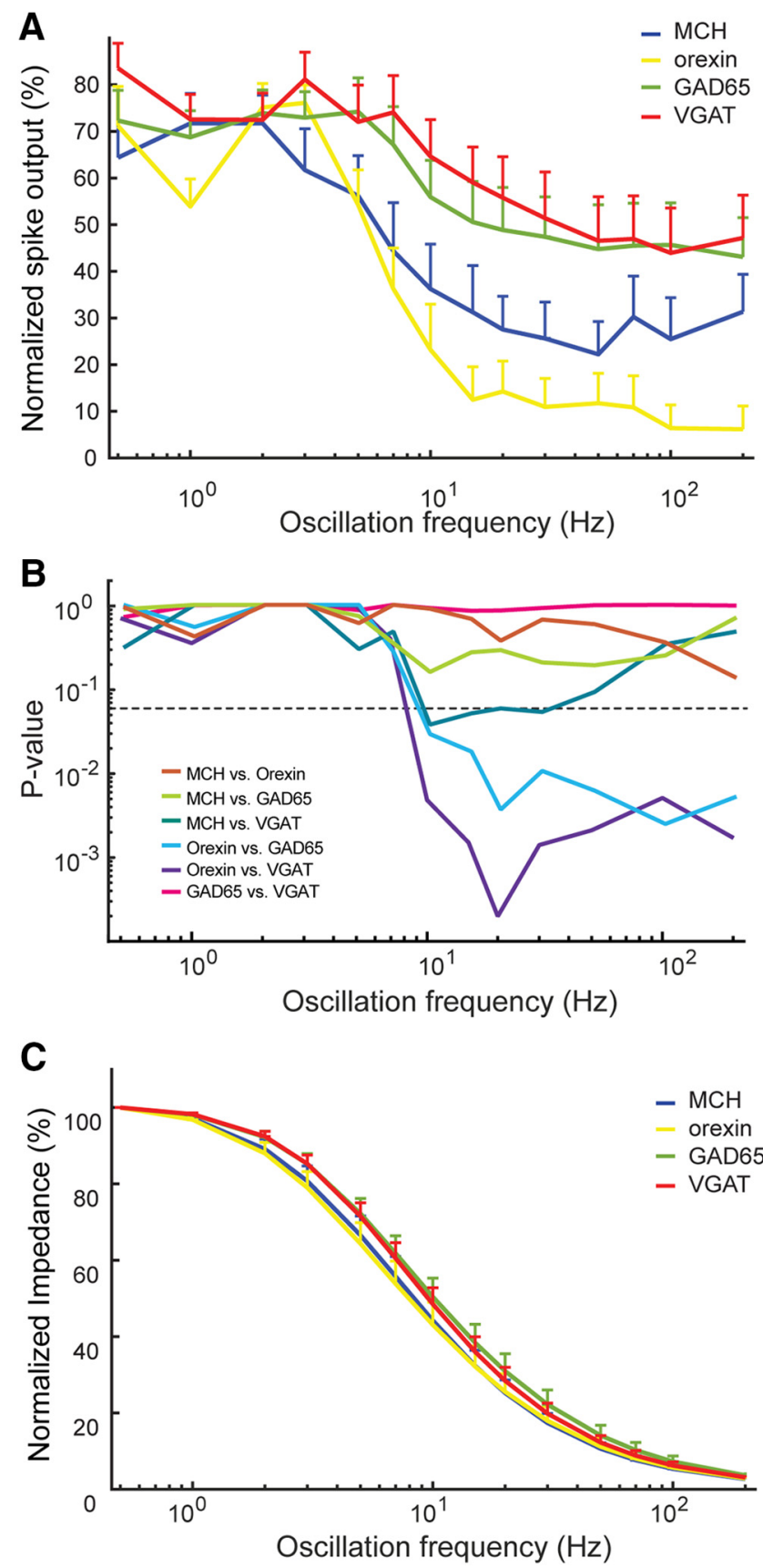

Figure 3. $\boldsymbol{A}$, Effect of input oscillation frequency on $\mathrm{LH}$ cell population spike outputs (same spike data as in Fig. 2, but normalized to the maximum spike output in each cell, to facilitate comparisons of oscillation frequency effects between cell classes). Values are mean \pm SEM. $\boldsymbol{B}$, Differences in population spike outputs across oscillation frequencies. The $y$-axis shows adjusted $p$ values of a two-way repeated-measures ANOVA with Tuckey's multiple comparison correction, for the four cell types and 14 input oscillation frequencies (ANOVA: interaction, $F_{(36,672)}=1.907$; $p=0.0013)$. $\boldsymbol{C}$, Effect of input oscillation frequency on LH cell population membrane impedances (same impedance data as in Fig. 2, but normalized to the maximum impedance in each cell). Values are mean \pm SEM.

normalized membrane impedances in the four $\mathrm{LH}$ cell types (Fig. 3C). 
A
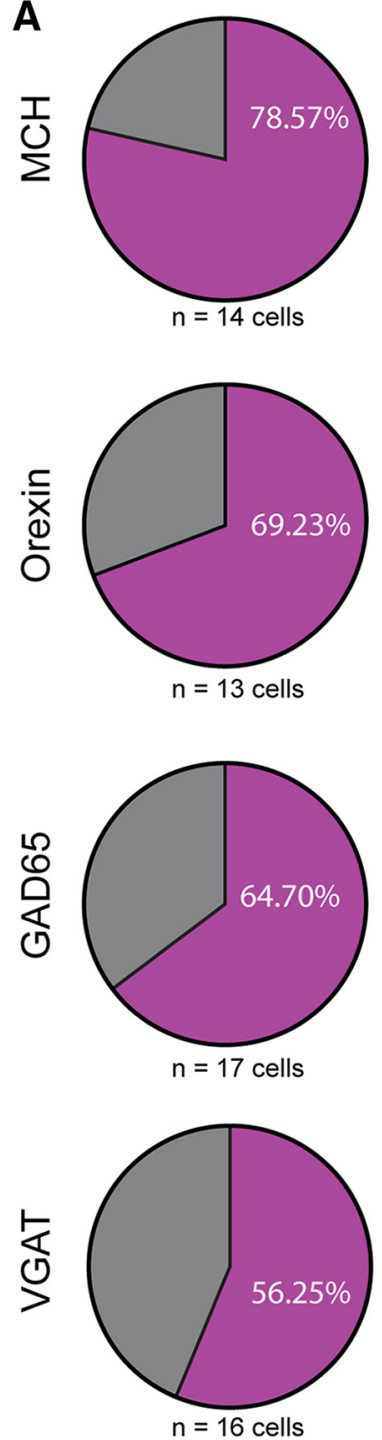

actively-tuned

passively-tuned actively-tuned examples
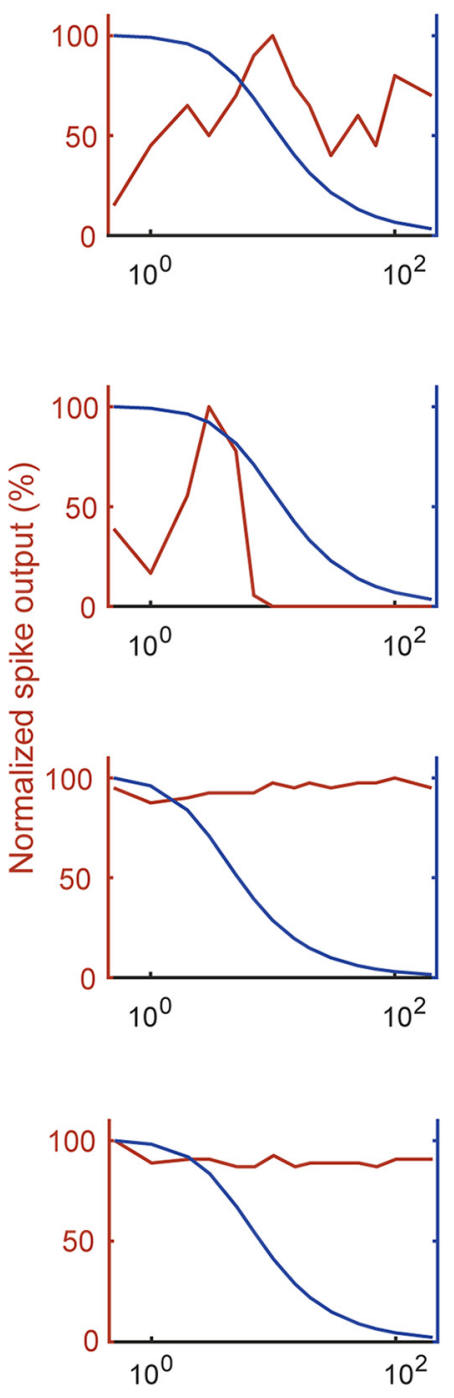

Oscillation frequency $(\mathrm{Hz})$ passively-tuned examples
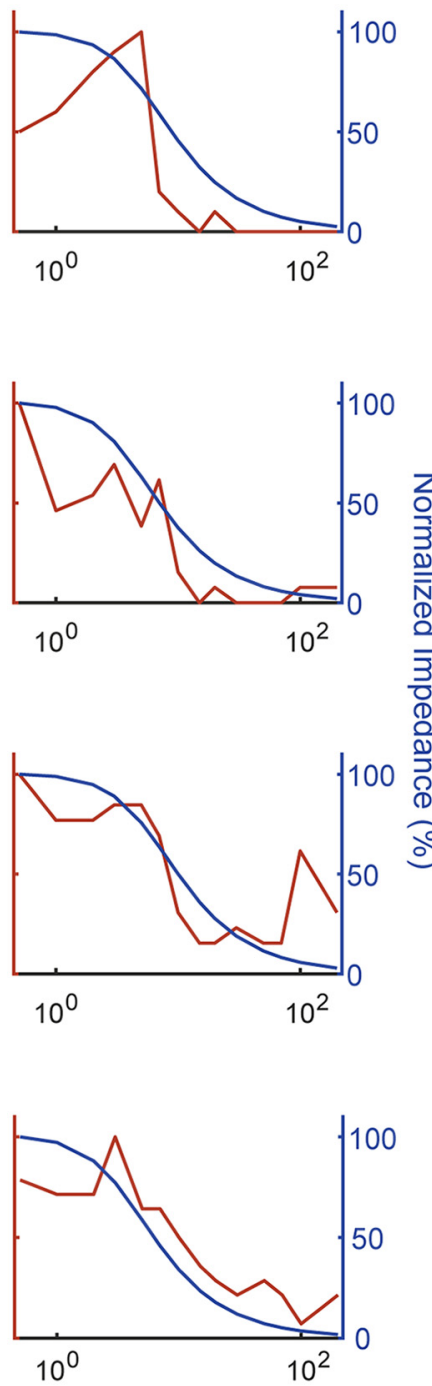

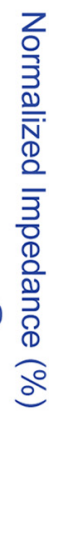

B

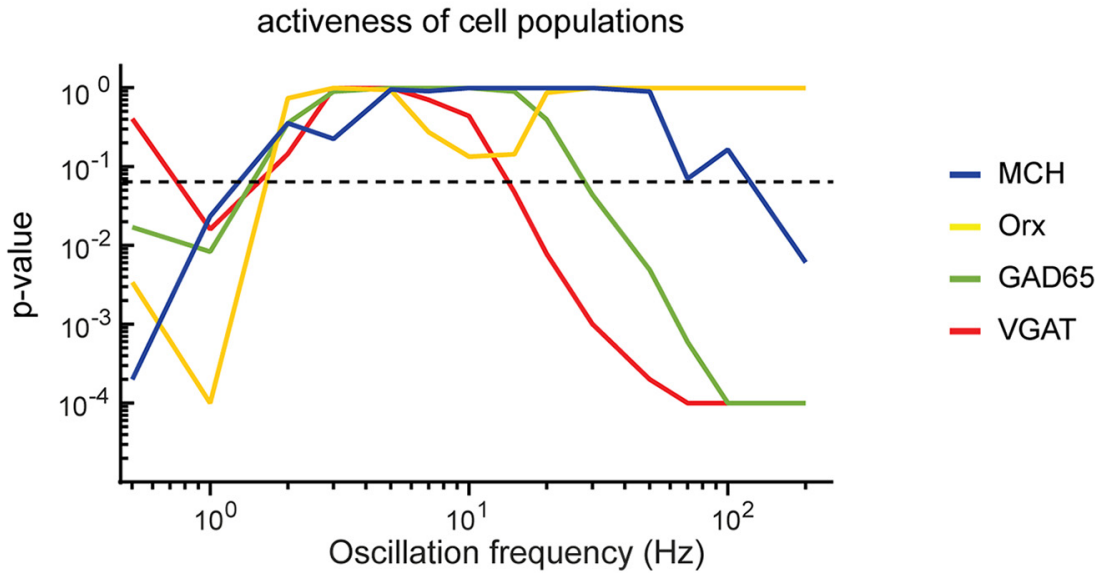

Figure 4. A, left, Pie charts depicting the percentage of actively-tuned cells (cells whose normalized spike frequency significantly differs from its normalized impedance magnitude), and passively-tuned cells (cells whose normalized spike frequency did not 


\section{continued}

significantly differ from its normalized impedance magnitude). To group neurons into these categories, firing and impedance profiles of each individual cell were compared using a paired $t$ test with correction for multiple comparisons by controlling the false discovery rate (two-stage step-up method of Benjamini, Krieger, and Yekutieli). Middle, Examples of individual actively-tuned cells. Right, Examples of individual passively-tuned cells. B. Activeness of cell populations (statistical difference between normalized spike frequency and normalized impedance of each cell type, across input oscillation frequencies, $\mathrm{n}$ numbers for each cell type are as indicated in $\boldsymbol{A}$. The $y$-axis shows adjusted $p$-values from paired $t$ tests with correction for multiple comparisons by controlling the false discovery rate (two-stage step-up method of Benjamini, Krieger, and Yekutieli).

\section{Frequency preference variation of individual cells within each molecularly-defined subnetwork}

We next investigated the differences between the impedance-predicted and experimentally-observed frequency-tuning of $\mathrm{LH}$ cell firing at the level of individual neurons. Within each molecularly-distinct class, individual neurons displayed similar frequency-tuning of impedance (as was the case also between classes; Fig. 3C), but differed substantially in frequency-tuning of firing (Fig. $4 A)$. As the input oscillation frequency increased, the firing rate decay mirrored the impedance decay in some cells (Fig. $4 A$, typical examples in right column), but strikingly deviated from impedance in other cells (Fig. $4 A$, typical examples in middle column). By quantifying and analyzing the difference between normalized impedance and firing in each cell (see Materials and Methods), we estimated, within each cell type, the percentage of cells that were tuned passively (i.e. firing tuning similar to impedance tuning) or actively (firing tuning significantly deviating from impedance tuning; Fig. $4 A$, left column). This revealed that within each cell type, the majority of cells were actively tuned, but some cell classes contained more "active" cells than others $(\mathrm{MCH}>$ orexin > GAD65 > VGAT; Fig. 4A).

Finally, we analyzed how "cell activeness" (difference between observed and impedance-predicted firing) varies as a function of input oscillation frequency within each cell type (Fig. 4B). Active tuning (significant difference between observed and impedance-predicted firing) was present in all cell types at low frequencies $(<1 \mathrm{~Hz})$, where firing was lower than expected from impedance (Fig. 4B). However, as input oscillation frequency increased, the frequency dependence of orexin population firing became indistinguishable from the frequency dependence of orexin cell impedance, with both sharply decaying as oscillation frequency increased (Fig. 4B). In contrast, VGAT and GAD65 populations (and to a lesser extent the $\mathrm{MCH}$ population) maintained substantial firing in the $\gamma$-fast frequency range $(30-200 \mathrm{~Hz}$; Fig. 4B). Thus, orexin neuron firing is subject to steep impedance-associated decay during $\gamma$ input, but non-orexin neurons resist this decay and maintain firing during $\gamma$ input.

\section{Discussion}

Cell-type-specific control of LH firing is important for normal physiology (avoiding contradictory LH outputs), for basic research (studying the role of specific LH outputs), and potentially for clinical applications (controlling sleep and appetite in obese or insomniac patients). In this study, we found that such cell-type-specific control can, unexpectedly, be achieved by varying the frequency of electrical oscillations in the LH. Specifically, we found significant differences in frequency dependence of orexin and non-orexin cell firing (Fig. 2), which were especially striking in orexin versus VGAT or GAD65 neurons (Fig. $3 B$ ), and were not explained by cell-type-specific variation in passive membrane impedances (Fig. 3C). Thus, distinct cell classes in the LH network show distinct frequency preferences for spike generation. Orexin neurons show a preference for low frequencies $(<10 \mathrm{~Hz})$, while non-orexin neurons are significantly driven by low and high (10-200 $\mathrm{Hz}$ ) frequencies.

The monotonic decay in membrane impedance that occurs as oscillation frequency is increased would be expected to produce concurrent monotonic decay in firing (Pike et al., 2000). We observed significant deviations of LH firing rates from this impedance-predicted decay (Fig. 4). Understanding the origins of these deviations is an important, but complex, problem for future study. In theory, these deviations can arise from differential expression of many different types of voltage-gated ion channels (calcium, sodium, potassium, or nonselective channels may all contribute: Puil et al., 1986; Hutcheon et al., 1996), as well as from differences in dendritic geometry (Mainen and Sejnowski, 1996). Only a limited knowledge of these parameters currently exists for the different LH cell types (Li et al., 2002; van den Pol et al., 2004; Schöne et al., 2011; Karnani et al., 2013; Romanov et al., 2017). To fully define these parameters in future studies, a comprehensive transcriptomic, pharmacological, and structural comparison of LH cell types and circuits would be necessary, together with modeling approaches.

In terms of physiological significance, the oscillation literature has focused largely on concepts such as input selection and plasticity, consolidation of learned information, representation of phase information, or binding cell assemblies (Buzsáki and Draguhn, 2004). Our results could be considered an example of assembly binding, where, as oscillation frequency is increased, the LH functional assembly shifts from VGAT-GAD65-MCH-orexin to VGAT-GAD65-MCH. Based on known properties of orexin and non-orexin neurons, it is possible to speculate about possible benefits of this shift. One benefit could be to remove an orexin-associated stress state. Orexin activity evokes physiologic hallmarks of stress and creates behavioral aversion (Suzuki et al., 2005; Johnson et al., 2010; Heydendael et al., 2014; Bonnavion et al., 2015). In some contexts, for example eating or formation of food preference driven by $\mathrm{VGAT}_{\mathrm{LH}}$ and $\mathrm{MCH}_{\mathrm{LH}}$ neurons, respectively (Domingos et al., 2013; Jennings et al., 2015), it may be important not to associate a stress/aversion signal with food. Consistent with this, in vivo recordings from 
orexin cells show that they are relatively inactive during eating (González et al., 2016). Another, related, benefit would be to create an optimal body state for energy storage. Based on body weight phenotypes resulting from inactivation of the different LH cells, one can view orexin neurons as a natural signal for weight loss, because their inactivation produces weight gain (Hara et al., 2001; González et al., 2016). In contrast, non-orexin neurons can be viewed as a natural signal for weight gain, because $\mathrm{MCH}$ and VGAT cell inactivation produces weight loss (Shimada et al., 1998; Whiddon and Palmiter, 2013; Jennings et al., 2015); while chemogenetic LH GAD65 cell activation does not change body weight (our unpublished data). By removing the energy-expending orexin drive, $\gamma$ oscillations may shift LH output to favor weight gain. An important direction for further research probing causal importance of $\gamma$-control of LH cells would be to use some (yet unknown) methods for abrogating the influence of $\gamma$ oscillations on orexin neurons in vivo.

In summary, our study demonstrates an unexpected way of controlling the firing of orexin versus non-orexin LH neurons. Such cell-type-specific LH control was previously thought to be achievable only by cell-type-selective chemical signals, but our results now show that nonselective electrical input can create cell-type-specific effects on hypothalamic firing. This insight opens up new avenues for future research on how this novel control mode can be utilized physiologically via internally-occurring hypothalamic oscillations (Carus-Cadavieco et al., 2017), or, in theory, therapeutically, via a deep-brain-stimulation paradigm promoting a particular oscillation (Maling et al., 2012; Sun et al., 2015). Considering the pivotal role of the LH in physiology and behavior, this reveals an important dimension of controlling the functions and malfunctions of this brain region.

\section{References}

Adamantidis AR, Zhang F, Aravanis AM, Deisseroth K, de Lecea L (2007) Neural substrates of awakening probed with optogenetic control of hypocretin neurons. Nature 450:420-424. CrossRef Medline

Apergis-Schoute J, lordanidou P, Faure C, Jego S, Schone C, AittaAho T, Adamantidis A, Burdakov D (2015) Optogenetic evidence for inhibitory signaling from orexin to $\mathrm{MCH}$ neurons via local microcircuits. J Neurosci 35:5435-5441. CrossRef

Bonnavion P, Jackson AC, Carter ME, de Lecea L (2015) Antagonistic interplay between hypocretin and leptin in the lateral hypothalamus regulates stress responses. Nat Commun 6:6266. CrossRef Medline

Boutrel B, Kenny PJ, Specio SE, Martin-Fardon R, Markou A, Koob GF, de Lecea L (2005) Role for hypocretin in mediating stressinduced reinstatement of cocaine-seeking behavior. Proc Natl Acad Sci USA 102:19168-19173. CrossRef Medline

Burdakov D, Gerasimenko O, Verkhratsky A (2005) Physiological changes in glucose differentially modulate the excitability of hypothalamic melanin-concentrating hormone and orexin neurons in situ. J Neurosci 25:2429-2433. CrossRef

Burdakov D, Jensen LT, Alexopoulos H, Williams RH, Fearon IM, O'Kelly I, Gerasimenko O, Fugger L, Verkhratsky A (2006) Tandempore $\mathrm{K}+$ channels mediate inhibition of orexin neurons by glucose. Neuron 50:711-722. CrossRef Medline

Burdakov D, Karnani MM, Gonzalez A (2013) Lateral hypothalamus as a sensor-regulator in respiratory and metabolic control. Physiol Behav 121:117-124. CrossRef Medline
Buzsáki G, Draguhn A (2004) Neuronal oscillations in cortical networks. Science 304:1926-1929. CrossRef Medline

Buzsáki G, Wang XJ (2012) Mechanisms of gamma oscillations. Annu Rev Neurosci 35:203-225. CrossRef Medline

Cardin JA, Carlén M, Meletis K, Knoblich U, Zhang F, Deisseroth K, Tsai LH, Moore Cl (2009) Driving fast-spiking cells induces gamma rhythm and controls sensory responses. Nature 459:663-667. CrossRef Medline

Carus-Cadavieco M, Gorbati M, Ye L, Bender F, van der Veldt S, Kosse C, Börgers C, Lee SY, Ramakrishnan C, Hu Y, Denisova N, Ramm F, Volitaki E, Burdakov D, Deisseroth K, Ponomarenko A, Korotkova T (2017) Gamma oscillations organize top-down signalling to hypothalamus and enable food seeking. Nature 542:232236. CrossRef Medline

Chemelli RM, Willie JT, Sinton CM, Elmquist JK, Scammell T, Lee C, Richardson JA, Williams SC, Xiong Y, Kisanuki Y, Fitch TE, Nakazato M, Hammer RE, Saper CB, Yanagisawa M (1999) Narcolepsy in orexin knockout mice: molecular genetics of sleep regulation. Cell 98:437-451. Medline

Colgin LL, Denninger T, Fyhn M, Hafting T, Bonnevie T, Jensen O, Moser MB, Moser El (2009) Frequency of gamma oscillations routes flow of information in the hippocampus. Nature 462:353357. CrossRef Medline

Domingos Al, Sordillo A, Dietrich MO, Liu ZW, Tellez LA, Vaynshteyn J, Ferreira JG, Ekstrand MI, Horvath TL, de Araujo IE, Friedman JM (2013) Hypothalamic melanin concentrating hormone neurons communicate the nutrient value of sugar. Elife 2:e01462. CrossRef Medline

González JA, Jensen LT, lordanidou P, Strom M, Fugger L, Burdakov D (2016) Inhibitory interplay between orexin neurons and eating. Curr Biol 26:2486-2491. CrossRef Medline

Gray CM, Singer W (1989) Stimulus-specific neuronal oscillations in orientation columns of cat visual cortex. Proc Natl Acad Sci USA 86:1698-1702. Medline

Gutfreund Y, Yarom Y, Segev I (1995) Subthreshold oscillations and resonant frequency in guinea-pig cortical neurons: physiology and modelling. J Physiol 483 [Pt 3]:621-640. CrossRef

Hara J, Beuckmann CT, Nambu T, Willie JT, Chemelli RM, Sinton CM, Sugiyama F, Yagami K, Goto K, Yanagisawa M, Sakurai T (2001) Genetic ablation of orexin neurons in mice results in narcolepsy, hypophagia, and obesity. Neuron 30:345-354. Medline

Herrera CG, Cadavieco MC, Jego S, Ponomarenko A, Korotkova T, Adamantidis A (2016) Hypothalamic feedforward inhibition of thalamocortical network controls arousal and consciousness. Nat Neurosci 19:290-298. CrossRef

Heydendael W, Sengupta A, Beck S, Bhatnagar S (2014) Optogenetic examination identifies a context-specific role for orexins/ hypocretins in anxiety-related behavior. Physiol Behav 130:182190. CrossRef Medline

Hutcheon B, Miura RM, Puil E (1996) Subthreshold membrane resonance in neocortical neurons. J Neurophysiol 76:683-697. CrossRef Medline

Jego S, Glasgow SD, Herrera CG, Ekstrand M, Reed SJ, Boyce R, Friedman J, Burdakov D, Adamantidis AR (2013) Optogenetic identification of a rapid eye movement sleep modulatory circuit in the hypothalamus. Nat Neurosci 16:1637-1643. CrossRef Medline Jennings JH, Ung RL, Resendez SL, Stamatakis AM, Taylor JG, Huang J, Veleta K, Kantak PA, Aita M, Shilling-Scrivo K, Ramakrishnan C, Deisseroth K, Otte S, Stuber GD (2015) Visualizing hypothalamic network dynamics for appetitive and consummatory behaviors. Cell 160:516-527. CrossRef Medline

Johnson PL, Truitt W, Fitz SD, Minick PE, Dietrich A, Sanghani S, Träskman-Bendz L, Goddard AW, Brundin L, Shekhar A (2010) A key role for orexin in panic anxiety. Nat Med 16:111-115. CrossRef Medline

Karnani MM, Apergis-Schoute J, Adamantidis A, Jensen LT, de Lecea L, Fugger L, Burdakov D (2011) Activation of central orexin/ hypocretin neurons by dietary amino acids. Neuron 72:616-629. CrossRef Medline 
Karnani MM, Szabó G, Erdélyi F, Burdakov D (2013) Lateral hypothalamic GAD65 neurons are spontaneously firing and distinct from orexin- and melanin-concentrating hormone neurons. J Physiol 591:933-953. CrossRef Medline

Kosse C, Schöne C, Bracey E, Burdakov D (2017) Orexin-driven GAD65 network of the lateral hypothalamus sets physical activity in mice. Proc Natl Acad Sci USA 114:4525-4530. CrossRef Medline

Leung LS, Yim CY (1986) Intracellular records of theta rhythm in hippocampal CA1 cells of the rat. Brain Res 367:323-327. Medline

Li Y, Gao XB, Sakurai T, van den Pol AN (2002) Hypocretin/Orexin excites hypocretin neurons via a local glutamate neuron-A potential mechanism for orchestrating the hypothalamic arousal system. Neuron 36:1169-1181. CrossRef

Madisen L, Zwingman TA, Sunkin SM, Oh SW, Zariwala HA, Gu H, $\mathrm{Ng}$ LL, Palmiter RD, Hawrylycz MJ, Jones AR, Lein ES, Zeng $\mathrm{H}$ (2010) A robust and high-throughput Cre reporting and characterization system for the whole mouse brain. Nat Neurosci 13:133140. CrossRef Medline

Mainen ZF, Sejnowski TJ (1996) Influence of dendritic structure on firing pattern in model neocortical neurons. Nature 382:363-366. CrossRef Medline

Maling N, Hashemiyoon R, Foote KD, Okun MS, Sanchez JC (2012) Increased thalamic gamma band activity correlates with symptom relief following deep brain stimulation in humans with Tourette's syndrome. PLoS One 7:e44215. CrossRef Medline

Pike FG, Goddard RS, Suckling JM, Ganter P, Kasthuri N, Paulsen O (2000) Distinct frequency preferences of different types of rat hippocampal neurones in response to oscillatory input currents. $J$ Physiol 529 [Pt 1]:205-213. Medline

Puil E, Gimbarzevsky B, Miura RM (1986) Quantification of membrane properties of trigeminal root ganglion neurons in guinea pigs. J Neurophysiol 55:995-1016. CrossRef Medline

Romanov RA, Zeisel A, Bakker J, Girach F, Hellysaz A, Tomer R, Alpár A, Mulder J, Clotman F, Keimpema E, Hsueh B, Crow AK, Martens H, Schwindling C, Calvigioni D, Bains JS, Máté Z, Szabó G, Yanagawa Y, Zhang MD, et al. (2017) Molecular interrogation of hypothalamic organization reveals distinct dopamine neuronal subtypes. Nat Neurosci 20:176-188. CrossRef Medline

Sakurai T (2014) The role of orexin in motivated behaviours. Nat Rev Neurosci 15:719-731. CrossRef Medline

Salinas E, Sejnowski TJ (2001) Correlated neuronal activity and the flow of neural information. Nat Rev Neurosci 2:539-550. CrossRef Medline

Saper CB, Chou TC, Scammell TE (2001) The sleep switch: hypothalamic control of sleep and wakefulness. Trends Neurosci 24: 726-731. Medline

Schöne C, Venner A, Knowles D, Karnani MM, Burdakov D (2011) Dichotomous cellular properties of mouse orexin/hypocretin neurons. J Physiol 589:2767-2779. CrossRef Medline
Schöne C, Apergis-Schoute J, Sakurai T, Adamantidis A, Burdakov D (2014) Coreleased orexin and glutamate evoke nonredundant spike outputs and computations in histamine neurons. Cell Rep 7:697-704. CrossRef Medline

Shimada M, Tritos NA, Lowell BB, Flier JS, Maratos-Flier E (1998) Mice lacking melanin-concentrating hormone are hypophagic and lean. Nature 396:670-674. CrossRef Medline

Soltesz I, Deschênes M (1993) Low- and high-frequency membrane potential oscillations during theta activity in CA1 and CA3 pyramidal neurons of the rat hippocampus under ketamine-xylazine anesthesia. J Neurophysiol 70:97-116. CrossRef Medline

Stuber GD, Wise RA (2016) Lateral hypothalamic circuits for feeding and reward. Nat Neurosci 19:198-205. CrossRef Medline

Sun Y, Giacobbe P, Tang CW, Barr MS, Rajji T, Kennedy SH, Fitzgerald PB, Lozano AM, Wong W, Daskalakis ZJ (2015) Deep brain stimulation modulates gamma oscillations and theta-gamma coupling in treatment resistant depression. Brain Stimul 8:10331042. CrossRef Medline

Suzuki M, Beuckmann CT, Shikata K, Ogura H, Sawai T (2005) Orexin-A (hypocretin-1) is possibly involved in generation of anxiety-like behavior. Brain Res 1044:116-121. CrossRef Medline van den Pol AN, Acuna-Goycolea C, Clark KR, Ghosh PK (2004) Physiological properties of hypothalamic $\mathrm{MCH}$ neurons identified with selective expression of reporter gene after recombinant virus infection. Neuron 42:635-652. Medline

Venner A, Anaclet C, Broadhurst RY, Saper CB, Fuller PM (2016) A novel population of wake-promoting GABAergic neurons in the ventral lateral hypothalamus. Curr Biol 26:2137-2143. CrossRef Medline

Vong L, Ye C, Yang Z, Choi B, Chua S Jr, Lowell BB (2011) Leptin action on GABAergic neurons prevents obesity and reduces inhibitory tone to POMC neurons. Neuron 71:142-154. CrossRef

Whiddon BB, Palmiter RD (2013) Ablation of neurons expressing melanin-concentrating hormone $(\mathrm{MCH})$ in adult mice improves glucose tolerance independent of $\mathrm{MCH}$ signaling. J Neurosci 33: 2009-2016. CrossRef Medline

Williams RH, Jensen LT, Verkhratsky A, Fugger L, Burdakov D (2007) Control of hypothalamic orexin neurons by acid and $\mathrm{CO} 2$. Proc Natl Acad Sci USA 104:10685-10690. CrossRef Medline

Yamamoto J, Suh J, Takeuchi D, Tonegawa S (2014) Successful execution of working memory linked to synchronized highfrequency gamma oscillations. Cell 157:845-857. CrossRef

Yamanaka A, Beuckmann CT, Willie JT, Hara J, Tsujino N, Mieda M, Tominaga M, ichi Yagami K, Sugiyama F, Goto K, Yanagisawa M, Sakurai T (2003) Hypothalamic orexin neurons regulate arousal according to energy balance in mice. Neuron 38:701-713. CrossRef 